\title{
Religious instruction in public schools in view of the fundamental right to religious freedom: A Christian ethical perspective
}

\begin{abstract}
Religious instruction in public schools in view of the fundamental right to religious freedom: A Christian ethical perspective

This article examines the way religious instruction can be arranged and executed in a liberal democratic society. Several options for the implementation of the fundamental right of religious freedom are investigated as well as the bearing of each of these on religious instruction in public schools. The article concludes that the active plural model for the implementation of religious freedom offers the best solution when it is measured within the framework of religious tolerance and peace. This option entails that pupils in public schools should be permitted to observe their respective religions, to wear religious symbols and to be instructed in the religion of their choice. They should also be taught about other religions in order to develop respect for people of other religious persuasions.
\end{abstract}

\section{INTRODUCTION}

Religion and religious freedom have become prominent topics in the contemporary human rights discourse. Where religion was seen in the recent past as a negative force in cultivating an ethos of human rights, scholars nowadays recognise the importance of religion in this process. Witte (2007:335) explains this trend in a recent book where he indicated that: "religion is an in eradicable condition of human lives and human communities. Religions invariably provide many of the sources and 'scales of values' by which many persons and communities govern themselves. Religions inevitably help to define the meanings and measures of shame and regret, restraint and respect, responsibility and restitution that a human rights regime presupposes. Religions must thus be seen as indispensable allies in the modern struggle for human rights. Excluding them from the struggle is impossible, indeed catastrophic. Including them by enlisting their unique resources and protecting their unique rights, is vital to enhancing the regime of human right." For this reason, new ways and structures for the application of the fundamental right to religious freedom are on the agenda of scholars in the various fields of human rights.

At the annual sessions of the United Nation's Human Rights Council, the topic of religious instruction within the framework of the fundamental right to religious freedom is constantly on the agenda for discussion and resolutions. The regular question is whether religious instruction should take place in public schools and if so, how it should be implemented to do justice to the fundamental right to religious freedom in a constitutional state? This constant attention to the specific topic can be attributed to four trends in modern societies. These are:

- The expanding human rights environment due to the influence of the Universal Declaration of Human Rights of the United Nations (1948) and the global trend of constitutionalism. 
- The growing interest in the ethics of human rights by religions and religious institutions.

- The emerging religious fundamentalism in virtually all global religions with its urge for religious instruction in public schools and its rejection of neutralism and the idea of a secular political dispensation (see Vorster, 2008:83; Antoun, 2001:153 \& Riddell, 2004:72).

- The emergence of contemporary religious intolerance due to the rise of religious extremism, which has the potential of social unrest and violence (Milton-Edwards, 2005:70; Aran, 1991:265; Sutton \& Vertigans, 2005:76).

This article examines the way in which religious instruction in schools can take place within the framework of the fundamental right to religious freedom. The central theoretical argument is that secularism in school education nurtures the inclination to intolerance and even violence in secular states and that a solution can be found in the implementation of an active plural model in the execution of religious freedom in a constitutional state. I will describe five models for the practical implementation of religious freedom and its implications for religious instruction in schools to explain the idea. These are the active theocratic model, the active state-religion model, the active secular model, the active universal model and the active plural model. I will conclude with arguments in favour of the active plural model.

\section{MODELS OF RELIGIOUS FREEDOM AND THEIR IMPLICATIONS FOR RELIGIOUS INSTRUCTION}

As far as the implementation of the fundamental right to freedom of religion is concerned, Hildegard Warnink, in her recent evaluation of models for implementing religious rights, distinguishes between the active neutral model and the active plural model (Warnink, 2005:1). In my opinion, further reflection on this issue opens doors for identifying another three models that function within the debates surrounding human rights. These three models can be referred to as the following: the active state-religion model, the active universal model, and the active theocratic model. I have explained these models in another publication (Vorster, 2007:149). In this article I intend to apply the implications of these models to religious instruction in public schools and to propose ways in which religious instruction can be arranged in such a way that it can advance religious tolerance and peace in a constitutional democracy.

\subsection{The active theocratic model}

The term active theocratic model refers to a political entity that is defined on the basis of a theocratic view of state and culture. In practice, this model means that a specific religion controls a country's rulers, and that the community at large is arranged according to the principles, laws and criteria applying to that specific religion. Other religions are accordingly either declared illegal or are, at most, tolerated as long as they do not interfere or clash with the ruling religion. History contains many examples of such rule. The great classic example quoted in history was that of the Roman Empire and its cult of the emperors (Walker, 1992:50). The emperor was allocated the status of a son of the gods, and everybody had to honour him accordingly. It is for this reason that Christians were persecuted during the first century after Christ when they desired to serve another God. Christendom, however, later on applied the same model. During the Middle Ages, the idea of Corpus Christianum, controlled by the pope, was applied. In terms of those times, this expression indicated a worldwide political entity (Cairns, 1982:165). No other religions were allowed to function. Even Christian movements such as the Cartharians and the Waldenes were prohibited. This model resulted in much bloodshed and was, to a certain extent, responsible for many religious conflicts during the Crusades and the post-Reformation religious wars in Europe. 
The idea was also prominent among both the Anabaptists and the Reformers. The Anabaptists wanted to establish the kingdom of God on earth by force (Bonhoeffer, 1995:305). In their view society should be arranged as a visible manifestation of the kingdom of God, and they rejected any notion of a civil authority. Calvin furnished the city-state of Geneva as a theocracy in which all other religions, as well as dissentions from the Reformed doctrine, were prohibited (Vorster, 1993:307; Witte, 2007:47 \& Tierney, 1996:46). He insisted that both church and state officials were to play complementary legal roles in the creation of a local Christian commonwealth and in the cultivation of the Christian citizen (Witte, 2007:78). His ideas were also furthered by his followers, such as Beza in Geneva, Althusius in Holland, Milton in England and the Puritans in New England.

The theocratic model has also been applied in Muslim states in the past where the state was organised according to the Shari'a, i.e., the laws of Islam as they developed through the ages (Blei, 1992:31). There is, at present, a revival of this model in various Muslim countries, and it proves to be the cause of many religious conflicts, as well as the violation of other rights - such as those of women, strangers, or foreigners. In some of these countries, it has been compulsory for the head of state to be a Muslim (Hashmi, 2006:1). This prerequisite is further evidence of the implications following in the wake of the active theocratic model. Another example of the active theocratic model can be traced to the Japanese constitution as implemented prior to the Second World War. The first article of this constitution prescribed that the population should acknowledge the godly origin of the emperor from the sun god, and that the emperor should be obeyed as such.

As a result of this model's failure to allow for or grant freedom of religion, speech, and conscience, it has led to extensive persecution, bloodshed, and violence in the past (Vorster, 2004:205). The religious wars that took place after the time of the Reformation could serve as an example of this. Similar religious persecutions take place presently, especially in countries where the theocratic model is actively implemented (United Nations, 2009:11). In modern times the theocratic model has particularly been propagated in the articles of faith of certain strands in the Reformed line of thought, as well as in the Muslim states under the control of the Shari'a.

The theocratic option has far-reaching implications for education. It entails that religious instruction is compulsory for all pupils and that the instruction must be instruction in one single religion. In this way one religion is forced on everyone, and everyone is expected to abide by the spirituality, rules, morals and values of the dominant religion. The purpose of education is to create a society founded on the religious principles and norms of the religion of the state. No other religious or secular norms are tolerated. People of other religious persuasions are forced by law to believe what they do not want to believe. Such a model violates the fundamental right of religious freedom, as well as the right of minorities to observe their own traditions and religious beliefs. Therefore, the fundamental legitimacy and soundness of this model should be questioned. ${ }^{1}$ Some remarks in evaluation of this follow:

- The Reformed tradition of the theocratic model causes the kingdom of God to become de facto an immanent political entity as Israel had been in times of the Old Testament. Modern Christian theology indicates clearly that neither Scripture nor Christian tradition offers any justification for a Christian theocratic model. Furthermore, the application of the model in this tradition devaluates the spread and sharing of the gospel through churches because society is directed externally by so-called Christian legislation and no longer from within by means of the influence of the gospel on the convictions of people.

1 In the meantime, confessions have been altered in almost all of the mainstream churches of the Reformed tradition - to such an extent that theocracies, as discussed above, can no longer be deducted from them (see Vorster, 1993:307). 
It would, in other words, mean that efforts are made to shape people's moral values by way of legislation instead of relying on primary, innermost conviction. In this way, a Christendom society - that cannot necessarily be characterised as a Christian society - is formed. ${ }^{2}$ Some signs of such a distortion of Christian values could be detected during the Apartheid regime in South Africa. The government, for example, prescribed Christian education, protected Christian moral criteria by way of regulations of censure, and refused other religions the opportunity to use the state controlled media. Such legislation promotes the image of Christianity, but does not actually promote or contribute towards the kingdom of God. It needs to be pointed out that the Kingdom becomes visible when people internalise the kingdom of Christ in their lives and profess and live up to the principles of the Kingdom through inner conviction. Laws do not make Christians - but the gospel indeed does.

- Christianity, Judaism and Islam have noble principles when it comes to respecting the human dignity of all people. This respect does not feature adequately in the active implementation of this model. Religion is a sensitive and highly emotional issue that deeply touches people's feelings and sense of dignity. If people are inhibited in the areas of religion, feelings of aggression and pain are awakened. Love for the fellow being must translate into consideration when it comes to these deepest feelings of others. In this sense, to really "love your neighbour" is rendered impossible by the theocratic model. Religious people should allow all others to lead their lives according to their own religious principles. On the other hand they can bear testimony of their own religion by way of persuasion and not by co-opting the tools of the state for the purpose of building a statereligion such as the Corpus Christianum of the Medieval Ages or the modern Shari'a states. The theocratic model deprives the authority of the day its God-given mission to maintain order and peace and to rule in such a way that everybody will have the choice to live in dignity. By restricting other religions, room is created for aggression and violence as has been repeatedly proven in history. It would mean that the authority, which should act as peacemaker, turns into the aggressor that uses education and forced religious instruction, according to the religion of the theocracy, to manipulate all citizens into a religious dispensation against the will of many. History proved that such an educational model is a recipe for intolerance and violence.

\subsection{The active state-religion model}

Closely related to the active theocratic model, but yet also different, is the active state-religion model. This model allows for contemporary rulers to single out and favour a specific religion, and to contribute to the advantage of its interests, while neglecting the others. This model differs from the active theocratic model in that it acknowledges and protects other religions in its rule and operates without using a fundamental text as basis. Even though authority does not base its state government on the ethical principles and criteria of the favoured religion, the freedom of religion is hampered in the sense of equal exposure.

These models existed mainly in the European nation states. The United Kingdom could serve as an appropriate example. The motto attached to external politics was "God, King and Country." Although this model no longer exists in a de jure manner, it still actually exists in a de facto manner. The queen still remains the head of the Anglican Church. This model can also be traced in the national anthem, "God save the Queen." The same is true of the pledge of allegiance in

2 The term "Christendom society" here indicates a society that broadly lives according to Christian norms and that upholds Christian festive days, but which is not necessarily a society of convinced Christians. A Christian society is a society of people who uphold certain principals and norms out of inner persuasion. 
the US and its maxim on their currency namely: "In God we trust". However, in the case of the UK and the US these customs are merely seen as ceremonial deism and it has no influence on the education policies.

In the previous dispensation in South Africa and other states within the major religious traditions, the state religion affects educational policies directly. The authority of the day gives preferential treatment to one single religion in public schools by incorporating the values of the state-religion into certain curricula and to arrange the school calendar according to the holy days of this particular religion. People of other religious persuasions are forced out of the system to their own expensive private institutions. Freedom of religion in this model is defined as the "right to arrange your own education and to pay for it".

Certain critical remarks can also be made about this model:

- As is the case with the active theocratic model, certain criteria and symbols are also forced on people belonging to other religions. Would it really be an expression of freedom of conscience if children of other convictions and religions sing "God save the Queen"? According to the theology of religions, it would be possible to reason that each individual can read his/her own god image into this anthem (Vorster, 1994:249). Such an interpretation, though, is not correct. The origin and historic course of expressions clearly indicate that the Christian view of God is prominent in this case.

- $\quad$ Agnostic and minority religions experience this model in the United Kingdom as excluding and discriminating in nature. Christians are forced by the biblical command to do unto others as they expect others to do unto them, to take a serious look at the possibilities of exclusion. A system that impairs proper respect and consideration for freedom of conscience and conviction cannot be regarded as ethically acceptable. Apart from this, the Christian religion is wrongly projected as a political entity, and this is contradictory to the dynamic character of the kingdom of God as a growing reality in the lives of people, and as something directed at innermost conviction and apparent from the witness offered by Christian people. Shaping the Kingdom ceremoniously into a mould of deism would be to darken and obscure the concrete reality of the Christian reign over everything.

- $\quad$ This model also does not answer to the demands and requirements that the Word sets for the leaders of the day. Authority must exercise justice and must protect and preserve peace. Inhibiting people's freedom of conscience, even if by means of symbolism only, cannot be viewed as justice in the fullest sense of the word. In times of the Old Testament, it was expected of even the theocratic government of the nation of God to protect the rights of strangers or 'foreigners' - i.e., those who worshipped other gods (De Vaux, 1988:930 \& Vorster, 2004:232). This model also poses a threat to peace as can clearly be seen from the public protest recently arising from among religious minorities in the United Kingdom and Australia.

- $\quad$ Such as model does not protect the religious rights of children and can even be typified as discriminatory because they are excluded from any form of financial assistance by the state. The parents are taxpayers but they cannot ensure the education of their children in the religion or worldview of their choice.

Furthermore, this model promotes inter-religious intolerance because children are in no position to learn about other religions and to develop respect for people of other convictions. They fail to bridge the "us-them" zones, and these divisions proved to be fertile soil for racism. Xenophobia and religiocentrism (Marger, 1994:7).

\subsection{The Active Neutral or Secular Model}

The neutral model currently functions in many constitutional democracies and the most well 
known of these are the USA and France. According to this model, church and state are completely separated. Freedom of religion is moved from the public sphere to the private domain. The government defines itself as secular, makes no religious or ideological choice and guarantees the freedom of all religions that conform to the norms of the constitution and the norms of general order and peace within the community. The government protects religions against discrimination within the limits that the law permits. This model emanated from the USA, and it is based on the so-called "free exercise clause" as opposed to the "establishment clause" that serves as the foundation for an active state religion model (Blei, 1992:112; Chaskalson, 1997:100; Vorster, 2004:209).

In spite of this choice the American Pledge of Allegiance still harbours the expression, "One nation under God," and the applicability of retaining this is widely debated between legal experts and ethicists within the USA (Kao, 2006:1). On the monetary units of the USA, the expression also appears that reads "In God we trust." However, as said before, judiciary circles view these expressions not as a movement away from the active neutral model, but as "ceremonial deism." (Kao, 2006:6). This means that these expressions no longer hold a contemporary religious meaning, and that they have no influence on interpreting the constitution (Van der Vyver, 1999:651). The reference to God is little more than a symbol of the nation's history.

The most extreme employment of the neutral model is found in the French law (Law nr. 2004-228 of 15 March 2004) in which school children are prohibited from wearing any religious symbols. Christian children are not allowed to wear necklaces with a cross, and Muslim children are not allowed to wear the veil (hijab). This law led to uprisings within cities of France in 2005, especially since Muslims are of the opinion that the flag of neutrality actually hides discrimination against them. Irrespective of these protests president Sarkozy of France banned the wearing of the Burkha by Muslim women in 2009. Although he contended that this step had nothing to do with religious freedom, but with the status of women in France, the fact remains that Muslim women can view this step as an infringement on the fundamental right to religious freedom.

The active neutral model moves all religious instruction to the private sphere, which entails that religious instruction becomes the entire responsibility of privately funded schools or religious institutions. In some instances provision will be made for pupils to learn about religions from an "objective" angle of approach. This option is popular in Western Liberal Democracies, but has come under pressure with the emergence of religious fundamentalism and the post-modernist worldview. Fundamentalists emphasise the holistic character of their religions and claim that no single sphere of life can be devoid of a religious praxis. According to their views schools should make provision for pupils to observe their religions by creating space for prayers, study of religious texts and observance of religious symbols such as wearing the hijab in the case of Muslim children and the cross in the case of Christian children. They also expect their own holy days to be respected. Post-modernist views regarding the religious freedom of individuals hold that the right of everybody to observe their religious rites in all public spheres also compromises the active neutral model (Vorster, 2009:163). Furthermore, the complaint by Muslims that the flag of neutrality actually hides discrimination against them is also not without grounds because in many Western Democracies, such as the UK and Australia, Christian holidays are still respected in school calendars and in the planning of academic years.

In addition to these arguments, the following critical remarks can be made about this model:

- Ceremonial deism does not satisfy belief because it is likely that all theistic religions view the degradation of references to God and other images of belief as blasphemous (Van der Vyver, 1999:651). For this reason, this model contains the potential for conflict.

- The Muslim's experience in France reveals another problem. The question is whether 
neutrality is possible. Can a government be ideologically neutral? Is it not so that a constitution and laws are written from within a given paradigm and life - and worldview? To my mind, neutrality is impossible when it comes to one's outlook on life. What Kuhn (1970:VII) and other scientists who followed him have to say about the paradigm drivenness of science also goes for the household of the state. In conjunction with Capetz, it is therefore reasonable to argue that neutrality (or secularism) embodies an ideological point of departure that influences constitutional drafting and the formulation of laws as much as does any other religion, ideology, or philosophy (Capetz, 2004:180).

- For this reason, neutrality cannot adequately guarantee religious freedom. The government must approach belief systems with a paradigm driven perception of what will be good for religions in general. According to Rawls (1987:4), such a perception must lead to the abuse of power. He says, "A public and workable agreement on a single and general comprehensive conception [of what is good] could be maintained only by the oppressive use of power." Indeed, this is what occurs when it comes to the concrete employment of this model in policies of religious instruction. The unrest following the promulgation of Law (nr. 2004-228 of 15 March 2004) in France proves this point.

- The promotion of neutrality in the public sphere cannot avoid limiting the role of religions - for instance, in the educational sphere. Freeing public education from religion opens the door for the promotion of secularism with all the consequences that this entails. Under the flag of neutrality, a value system (that can never actually be neutral) is developed that will determine the life norms of pupils. How can matters like sexual education, the teaching of history, and moral education be treated neutrally? As in the case of an active state religion, pupils are also ideologically influenced in the case of this model. The model therefore fails to guarantee religious freedom because it replaces religion in the public sphere with an ideology that the government of the day holds dear. In a sense it then becomes just another state-religion model. What is it but a violation of the fundamental right to religious freedom when the ideology of the governing party replaces a child's right to receive religious education of his choice in a state school? The same problem surfaces in the belief practices of people in correctional facilities and military units.

The limitation has bearing when religious actions are against the law. An example of this is the announcement by the constitutional court in South Africa that Rastafarians do not have the right to use cannabis as part of the practicing of their religious rituals since the use of this narcotic goes against the law that controls the use of damaging drugs. In the same manner, pacifists that claim religious grounds for their pacifism - for example, Jehovah's Witnesses - cannot necessarily refuse to do military service for the reason that the latter goes against the grain of their religious convictions. The government may determine that this kind of refusal is not in the interest of the country, and they may therefore not view the refusal as a religious right. As a consequence, Jehovah's Witnesses will not be able to claim religious freedom in order to avoid military service. In the same way, religions that practice polygamy will not be able to claim religious freedom when it comes to the practicing of polygamy if the law defines a marriage as a monogamous heterosexual commitment. Neutrality, therefore, has limitations.

\subsection{The Active Universal Model}

With the development of the theology of religions, the idea is propagated that the good of all religions should be sought - as well as what different religions have in common - and that this should be offered as a type of universal value system to all religious people. This religion is 
especially expressed on the level of spirituality and inter-religious worship gatherings, and on the level of the ethical. As a model within the recognition of the fundamental right to freedom of religion, this model implies that a universally accepted view of God is developed through means of an inter-religious education.

People should then understand that the God mentioned in the constitution is the God of all religions and faiths. In schools, in so-called religious education, the acceptability and applicability of each religion are investigated and weaved into a value system that steals the heart of all and is acceptable to people of different religious persuasions. This model can be found in the constitutional thought of India and Namibia. Under the guidance of a former minister of education in South Africa, Asmal, the foundations of the model has been imported into South Africa. It especially features in learning programs of so-called Life Orientation as a compulsory subject for all children. Chidester encourages children's participation in multi-faith religious practices at school because: "Through such participation, pupils can explore the diversity of religious life in South Africa, through sacred times and places, through stories and rituals, and through the different ways of imagining what it means to be human" (Chidester, 2001:31).

With this statement he envisions the aim of the universal model in South Africa.

The following critical remarks can be made concerning this idea:

- Gaining knowledge of the history and values of different religions is acceptable. It is important for pupils to learn about other religions besides their own. Such knowledge can even contribute to understanding and respect and can counter negative stereotyping of religions in the volatile, religious conflicts of today. However, the universal religious model goes further than that. It presents a modern active state religion model, or in its extreme form, an active theocratic model. A new religion is forced on everyone, and the same criticism goes for this than for the two above-mentioned models.

- With such a model, the government does not fulfil its God-given calling. Because this new religion is forced on everyone, the potential for religious conflict is large. People lose the space to enact their right to be instructed in the religion of their own choice and to build a value system that flows from their own religion. History teaches that such limitations contain the potential for social unrest, and there is no guarantee that history will not repeat itself in the application of this model.

The active universal model does not answer to the needs of people in a post-modernist and plural environment. It certainly does not solve the problems created by the contemporary search for meaningful religious observance and spirituality in society, particularly in the educational environment. Such an option will, like Van der Vyver (1999:651) argued regarding the ceremonial deism, raise the suspicion of religious intolerance when a religion, or a religious value system is reduced to a few "useful" and "positive" principles. The active universal option does not satisfy belief because it will be, as in the case of the active neutral option, likely that all theistic religions view the reduction of references to God, value and belief systems and other images of belief as blasphemous. This option as a foundation of a policy of religious instruction raises the possibility of religious intolerance because no religious person will feel free to observe his or her religion as a holistic religion comprising the totality of life. Religious people will also reject values emanating from other religious sources that do not bear the hallmark of their own confessions and creeds.

\subsection{The Active Plural Model}

This model is the opposite of the active neutral model. Where the active neutral model departs from the point of view that all religions should be moved from the public to the private sphere, 
this model necessitate that all religions should function in the public sphere. Research does not indicate whether this model functions fully in any constitutional democracy, but it is valid to claim that elements of the model are visible and possible in South Africa at the moment (Van der Vyver, 1999:635). In more detail, it can be said that this model provides all religious people with the opportunity to confess the religion of their choice, to observe it in public worship, and to profess it in the public sphere as long as no one else is placed under any obligation to do the same.

In his evaluation of the situation in the USA where the 'establishment clause' and the 'free exercise clause' provide support for the active neutral model, Hollenbach comes to the conclusion that the active neutral model leads to the total secularisation of the society and a dilapidation of the moral order. He pleads for more involvement of religions in the public sphere because: "There are significant groups of religious believers who are in fact corporately involved in public life and who contribute to the common good in peaceful and freedom-supporting ways" (Hollenbach, 2003:88).

Although he does not spell out his choice, his argumentation also moves in the direction of the active plural model. The implication of this model in the public sphere is the following: Public gatherings and the parliament, as well as opening ceremonies, begin with devotions. These actions can take place in two ways. People of different religions can gather individually, and each group can hold a devotional meeting within the practices and traditions of that religion. For instance, in schools, the parliament, and other public gatherings, Christians can gather for a Christian meeting with reading of Scripture, preaching of the Word, and prayer within the framework of Christian traditions. The same right is offered to other people of other religious persuasions. Agnostics are not forced to attend any of these opportunities, and nobody is forced to take part in a different religious meeting. Where such separate gatherings are not possible due to practical reasons, a single gathering can be held where spokespersons of the different religions get the opportunity to do a prayer on behalf of each religion. Each person is allowed to do it within the traditions and practices of his own religion, and nobody is expected to apply his practices in reduced form to prevent possible offence. Each religion receives the opportunity to function fully, based on its own principal foundations. This practice was in use at the Codesa negotiations for a new constitution in South Africa, and is currently the practice at several governmental events in this country.

In the field of education this model can be realised in the following way: a public school arranges time and space for private religious instruction. Adherents of each of the religions practiced in that particular community convene for separate religious instruction. The religious leaders of the particular religious communities do the instruction. In other words Christian children of a certain denomination convene to be instructed by a local minister or priest, Jewish children come together to be instructed by the local rabbi and Muslim children convene to be instructed by the imam. Children of agnostic persuasion are under no obligation to attend any of these meetings. Children and educators are permitted to wear religious symbols and to speak openly about their faith. This private religious instruction can be complemented with an open religious instruction where children can learn about other religions and where respect for other religions and religious people and willingness for religious dialogue can be nurtured.

The active plural model may encounter the following critical remarks:

- Some scholars argue that this model has the potential to polarise children along religious lines. Hollenbach (2003:92), for example, refers to Smith who warns against a further polarisation of society when these models are applied. He says that religions have a "fissiparous quality," which means that religions tend to draw boundaries between people and define in-group and out-group parties. However, Hollenbach is of the opinion that this 
danger only exists when people are confronted with religious extremism.

- $\quad$ Further to this argument children may experience religion as a separating force. Children are together in all other areas of instruction, but when it comes to religion they are separated.

- $\quad$ Religious extremists may misuse this model in an effort to proselytise children and in doing so may sow the seeds of disruption along religious lines.

- The question can also be asked whether the model is always practically attainable. Is it possible to give public schools, prisons, the Police Service and protection units the opportunity to function fully on equal basis?

- $\quad$ Agnostics and other minority groups may feel that they are 'engulfed' by religions, and that there is no space for non-religiosity.

- $\quad$ Furthermore, critics could ask whether this model does not have an element of universalism and will ultimately harm minority religions.

\section{CONCLUSION}

The five models discussed above have all functioned to some degree in the past or are functioning at present, although the last model is still relatively new in the human rights discourse. However, it seems that the active plural model is the best, and can especially be considered in plural societies. The following arguments can be offered in support of this choice:

- $\quad$ Such a model serves justice to all. Religious people can exercise the fundamental right of religious freedom by having their children educated in public schools in the religion of their choice.

- This model also enables all religions to function within the confines of their own principles without disturbance. Where the universal model wants to reduce religions and let them flow into one universal melting-pot religion, this model allows all religions to move in their own orbits.

- Its application in certain areas in South Africa shows that the model is practically attainable. Public schools can offer churches and other religious institutions the opportunity to draw up learning programs of their own for their religious group and to teach children at times and in places that the schools make available. In this way, the Roman Catholic Church community can teach Catholic children according to their own learning program, while other religions do the same. However, teaching must meet the standards for orderly governing and must not undermine the public order of a peaceful and responsible democracy.

- When this model is applied like this, it cannot move into universalism. Universalism only threatens when minorities do not receive the opportunity to practice or profess their own religion.

- $\quad$ In this model nobody must be forced to attend a certain religious observance of teaching. Agnostics should be free to remove themselves from religious practices.

- The active functioning of religions in the public sphere can contribute greatly to nation building because everyone claims moral principles and norms that are forming and constructive to the people of that religion.

- For Christian believers, this model offers the best space to express "love to all people" because it creates room for people to express their emotions within the spirituality of their religious persuasions. Consequently, the authorities can rest assured with the knowledge that everyone is provided with the space to function.

- Extremism, against which Hollenbach (2003:90) warns, remains a threat, but religious 
groups must calm extremist and fanatic groups themselves. The government can only be expected to act against such groups if they transgress the law.

The fundamental right of religious freedom can best be served where room is created for all to be fully human in the public and private spheres. Being fully human means to cradle the spirituality of one's religion and to build one's life on the foundations that the religion offers. That is what religious freedom is all about. Religious freedom aims to build respect for an individual person's own religious identity and not to force people into a whole where their identities are obliterated. Such freedom intends to serve freedom and not state totalitarianism and to further human rights without constraints. To my mind, the active plural model in school education will promote this principle the best.

\section{BIBLIOGRAPHY}

Antoun, R.T. 2001. Understanding Fundamentalism. Christian, Islamic, and Jewish Movements. Oxford: Altamira Press.

Aran, G. 1991. Jewish Zionist Fundamentalism: The Bloc of the Faithful in Israel (Gush Enumin). (In Marty, M.E. \& Appleby, R.S. eds. Fundamentalisms Observed, A study conducted by The American Academy of Arts and Sciences. Chicago: The University of Chicago Press, p. 265-344).

Blei, K. 1992. Freedom of religions and belief. Europe's story. Assen: Van Gorcum.

Bonhoeffer, D. 1995. Ethics. London: Simon \& Schuster.

Cairns, E.E. 1982. Christianity through the centuries. Grand Rapids: Zondervan.

Capetz, P.E. 2004. The first commandment as a theological and ethical principle. (In Brown, W.P. ed. The

Ten Commandments. The reciprocity of faithfulness. Louisville: Westminster John Knox p.175-185).

Chaskalson, G. 1997. State versus Solberg, 1997(10) BCLR 1348 (CC) Par 100.

Chidester, D. 2001. Multiple Voices: Challenges Posed for Religious Education in South Africa (In International Association of Religious Freedom. Religious Education in Schools, Ideas and Experiences from Around the World. Oxford: International Association of Religious Freedom. p. 20-43).

De Vaux, R. 1988. Ancient Israel. Its life and institutions. London: Longman \& Todd.

Hashmi, S. 2008. Cultivating a liberal Islamic ethos. Building an Islamic Civil Society. Presentation at the Society of Christian Ethics. Phoenix, Arizona, 6 January, 2006.

Hollenbach, D. 2003. The Common Good and Christian Ethic. Cambridge: Cambridge University Press.

Kao, G.Y. 2008. "One nation under God" or taking the Lord's name in vain? Christian reflections on the Pledge of Allegiance. Paper delivered at the Society of Christian Ethics. Phoenix, Arizona, 6 January, 2006.

Kuhn, T.S. 1970. The Structure of Scientific Revolutions. Chicago: The University of Chicago Press. Milton-Edwards, B. 2005. Islamic fundamentalism since 1945. London: Routledge.

Rawls, J. 1987. The idea of overlapping concensus. Oxford Journal of Legal Studies 1987. p. 1-15.

Riddell, P.G. 2004. Christians and Muslims. Pressures and potential in a post-9/11 world. Leicester: InterVarsity Press.

Sutton, P.W. \& Vertigans, S. 2005. Resurgent Islam. A Sociological Approach. Cambridge: Polity.

Tierney, B. 1996. Religious rights. A historical perspective (In Reynolds, N.B. \& Durham, W.C. Religious liberty in the Western World. Atlanta: Scholars Press p. 41-51).

United Nations, 2009. Civil and political rights, including the question of religious intolerance. Geneva: United Nations.

Van der Vyver, J.D. 1999. Constitutional Perspective of Church-State Relations in South Africa. Brigham Young University Law Review, 1999(2):645-661.

Vorster, J.M. 1993. Godsdiensvryheid in die lig van artikel 36 van die Nederlandse Geloofsbelydenis. In die Skriflig 27(3):307-321.

Vorster, J.M. 1994. Tendense in die teologie van die Wêreldraad van Kerke sedert 1948. Studia Historiae Ecclesiasticae, 20(2):234-253.

Vorster, J.M. 2004. Ethical perspectives on human rights. Potchefstroom: Potchefstroom Theological Publications. 
Vorster J.M. 2007. Christian attitude in the South African Liberal Democracy. Potchefstroom: Potchefstroomse Teologiese Publikasies.

Vorster, J.M. 2008 The challenge of contemporary religious fundamentalism. Pretoria: Unisa.

Walker, 1992. A history of the Christian Church. Edinburgh: T. \& T. Clark.

Warnink, H. 2005. Current issues in Belgium. Paper delivered at the conference on Church/State relations in South Africa on 27 October 2005 in Stellenbosch. (Copy in possession of author).

Witte, J. 2007. The reformation of rights. Law, religion and human rights in early modern Calvinism. Cambridge: University Press.

\section{TREFWOORDE}

Godsdiensvryheid

Godsdiensonderrig

Menseregte

Aktiewe neutrale opsie

Aktiewe plurale opsie

\section{KEY WORDS}

Religious freedom

Religious instruction

Human rights

Active neutral option

Active plural option

Prof JM (Koos) Vorster

Joostestraat 2

Potchefstroom

2531

Tel 0829227509

E-mail: Koos.Vorster@nwu.ac.za 